\title{
Analysis of the Composition of Selected Inserts Using Electron Microscopy
}

Nataša Náprstkováa ${ }^{1}$ Jaromír Cais ${ }^{1}$, Dana Stančeková ${ }^{2}$, Pavel Kraus ${ }^{1}$

${ }^{1}$ Faculty of Production Technology and Management, J. E. Purkyne University in Usti nad Labem. Pasteurova 3334/7, 40001 Usti nad Labem. Czech Republic.E-mail: naprstkova@fvtm.ujep.cz, cais@fvtm.ujep.cz, kraus@fvtm.ujep.cz ${ }^{2}$ Faculty of Mechanical Engineering, University of Žilina, Vel'ký diel, 01026 Zilina, Slovak Republic. E-mail: dana.stancekova@fstroj.uniza.sk

Using of cutting inserts is currently a normal part of the manufacturing process. The article deals with structural analysis and material selection of inserts for turning. Analysis of the composition of experimental inserts was made by electron microscopy, namely EDS analysis. EDS analysis is an analysis using an energy dispersive spectrometer. For this purpose was used EDS analyzer Bruker 16 which is part of a scanning electron microscope Tescan Vega 3. These analysis can provide a good picture of the structure and construction of inserts and their composition. This may assist in finding suitable cutting conditions. These analyzes were performed in other experiments performed at the Faculty of Production Technology and Management at Jan Evangelista Purkyně University in Ústí nad Labem.

Keywords: The cutting insert, chemical composition analysis, EDS

\section{Acknowledgement}

Authors are grateful for the support of grant SGS 2016 UJEP and of grant OP 2.2 No. CZ.1.07/2.2.00/28.0296-

\section{References}

[1] CAIS, J. (2015). Elektronova mikroskopie. Metalografie, Praha, CZ.1.07/2.3.00/45.00 29, ISBN 978-80-8630267-6 [online], 2015 [cit. 14. 5. 2016]. Available from <http://www.csvs.cz/projekty/2014_veda_pro_zivot/data/11_KA3_Jaromir_Cais_2_Elektronova_\%20mikroskopie_a_\%20EDS_\%20analyza_metodicka_priruck a.pdf>

[2] WEISS, V., SVOBODOVA, J. (2015). The Use of Colour Metallography and EDS for Identification of Chemical Heterogeneity of Selected Aluminium Alloys Copper and Zinc Alloyed. In: Manufacturing Technology, Vol. 15, No. 6, pp. 1048-1053. Czech Republic

[3] CZAJKOWSKA, A., KOSSAKOWSKI, P., WCIŚLIK, W., STASIAK-BETLEJEWSKA, R. (2013). Application of Electron Scanning Microscope in the Analysis of the Structure of Casting NonConformities Aimed at Optimization of Technological Process Parameters. In: Manufacturing Technology, Vol. 13, No. 2, pp. 164-169. Czech Republic

[4] Bruker Q4 TASMAN - the "Multi-Tool" in Metal Analysis [online], 2016 [cit. 3. 5. 2016]. Available from <http://trends.directindustry.com/bruker-elemental-gmbh/project-30028-124882.html>

[5] PETRU, J., ZLAMAL, T., MRKVICA, I., CEP, R. (2014). The Effect of Thermal Shocks on Wear of Exchangeable Sintered Carbide Inserts during the Cutting Process. In: Manufacturing Technology, Vol. 14, No. 4, pp. 590596. Czech Republic

[6] HUMÁR. A. (2008) Materialy pro rezne nastroje. MM Publishing, s.r.o., Prague, Czech Republic

[7] KORDIK, M., STRUHARNANSKY, J., MARTIKAN, A., STANCEKOVA, D., KUSMIERCZAK, S., MARTINCEK, J. (2016) Inserts Coating Influence on Residual Stress of Turned Outer Bearings. In: Manufacturing Technology, Vol. 16, No. 1, pp. 132-136. Czech Republic

[8] SVOBODOVA, J. (2014) SEM and EDS Analysis Used in Evaluation of Chemical Pre-treatment Based on Nanotechnology. In: Manufacturing Technology, Vol.14, No.3, pp. 461-467. Czech Republic

[9] SNAHNICAN, F. (2015). Deposition of Aluminium Oxide $\left(\mathrm{Al}_{2} \mathrm{O}_{3}\right)$ Coatings on Aluminium Substrate Using Anodizing Processes. In: Manufacturing Technology, Vol 15, No 3, pp. 423-428. Czech Republic

[10] KUSMIERCZAK, S. (2011). The Usage of Confocal Laser Microscope by Solving Students Projects, In: proceedings of International Miltidisciplinary Conference, 2011, Nyíregyháza, Hungary, pp.149-152

[11] MICHNA, S., KUSMIERCZAK, S. (2012). Praktická metalografie. 245 pp., UJEP, Usti nad Labem, Czech Republic. 
[12] TAVODOVA, M. Moznosti inovacii vyucby strojarskych technologii. In: Proceedings Zvysovani efektivnosti vzdelavacieho procesu prostrednictvom inovacnych prostriedkov, pp. 81-85. TU vo Zvolene, Zvolen, Slovakia.

[13] PETRU, J., SCHIFFNER, J., ZLAMAL, T., SADILEK, M., STANCEKOVA, D. (2015). Investigations of Cutting Tool Wear While Machining Inconel 718. In: Manufacturing Technology, Vol 15, No 3, pp. 396-403. Czech Republic.

[14] VALASEK, P. MÜLLER, M. (2014). Picture Analysis of Failure Areas of Particle Composites. In: Manufacturing Technology Vol 14, No 3, pp. 474-478. Czech Republic

[15] WEISS, V. (2012). Hodnoceni vlivu teploty a doby homogenizačniho žihani slitiny AlCu4MgMnz hlediska mikrostruktury, obrazove analyzy a metody EDX. In: Strojirenska technologie, Vol. 17, No. 5,6, p. 348-355. Czech Republic.

Paper number: M2016196

Copyright $\odot$ 2016. Published by Manufacturing Technology. All rights reserved. 